\title{
Tres poetas mexicanos
}

Se ha dado en hablar de surrealismo y con mucha razón, en la poesía contemporánea. Con la visita de Andre Bretón a México este año, anduvieron los poetas de ese país muy entusiasmados con la nueva tendencia, ¿ 0 diremos mejor, con la vieja tendencia?, ya que toda fórmula en arte es algo transitorio, algo destinado a morir pronto, vejez prematura. Breton es el crítico oficial del surrealismo, el que ha celebrado el método crítico-paranoico de Salvador Dalí, y naturalmente su estancia en México fué todo un acontecimiento. Los jóvenes poetas de México intensificaron por esos días la pasión del surrealismo que ya sentían desde algunos años. La obsesión sexual, el símbolo fálico, el delirio, la histeria, el hipnotismo, la nostalgia de la muerte, el suicidio, los sueños experimentales, sueños polutos, son frecuentes en la temática de los poetas de vanguardia. La experiencia irracional concreta de que habla Dali, la zona de la imaginación desconocida, es lo que el poeta tiene que comunicar en forma realista. El poeta no quiere ya ser entendido porque ni él mismo entiende lo que hace. El poema, igual que el cuadro surrealista, no se debe ni se puede explicar, pues tiene un valor intrínseco, ajeno al análisis razonado. Casi toda la poesía nueva de América cae bajo el frenesí surrealista y no es extraño que en tres libros de versos publicados en México durante el presente año veamos el espectro de esta escuela.

Elías Nandino, fervoroso propulsor de la poesía mexicana; 
ha publicado las poesías selectas de Salvador Novo, (I) sacadas de Veinte poemas, Espejo y Nuevo amor, más un poema inédito. Novo es el "enfant terrible" de las letras de su patria, anecdótico, audaz, lleno de contradicciones, de vibraciones y malicia. Lleno de un absoluto desprecio por el Modernismo, comenzó escribiendo cosas así:

¿Quién quiere jugar tennis con nopales y tunas

sobre la red de los telégrafos?

(Veinte poemas).

o usando ciertos recursos de esta escuela se vuelve contra ella en sátira violenta :

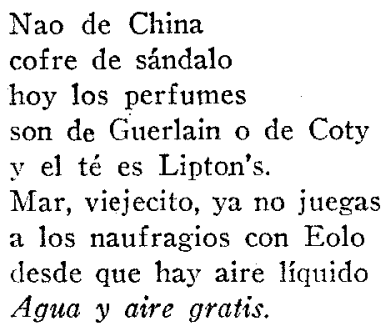

(Veinte poemas).

Este "sense of humour" se continúa en Espejo, en una for ma poética demasiado fácil, prosaica acaso, pero con cierto encanto reminiscente. En este libro aparece esa estrofa que yo considero la más feliz de este poeta:

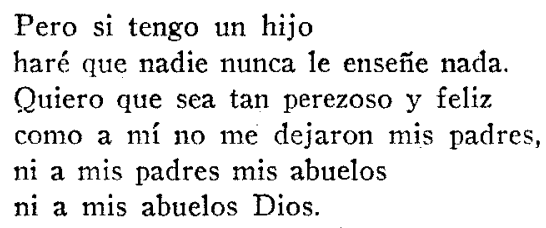

(Espejo).

Engañado por esta actitud, el poeta encuentra un día su casi

(1).-Salvador Novo, Poesias escogidas, Cuadernos México Nuevo, México, 1938, 42 p. 
verdad y brota entonces la exclamación de todo artista que todavía no ve su obra lograda:

Pero en mi lecho, solo, dulcemente, $\sin$ recuerdos, $\sin$ voz, siento que la poesía no ha salido de mí.

(Espejo).

En Nuevo amor llega Novo a esa apetecida madurez de expresión. Difícil encontrar algo más bello que su Glosa incompleta:

Dentro de estos cuatro muros pretendí ocultar mi dicha; pero el fruto, pero el aire ¿cómo me los guardaría?

si no fuera por su Breve romance de ansencia en que Novo rivaliza con los mejores poetas de la lengua:

Unico amor, ya tan mío que va sazonando el Tiempo; iqué bien nos sabe la ausencia cuando nos estorba el cuerpo! Mis manos te han olvidado pero mis ojos te vieron $y$ cuando es amargo el mundo para mirarte los cierro.

No quiero encontrarte nunca, que estás conmigo y no quiero que despedace tu vida lo que fabrica mi sueño. Como un día me la diste viva tu imagen poseo, que a diario lavan mis ojos con lágrimas tu recuerdo. Otro se fué, que no tú, amor que clama el silencio si mis brazos y tu boca con las palabras partieron. Otro es éste, que no yo, mudo, conforme y eterno como este amor, ya tan mío que irá conmigo muriendo. 
Orientado hacia esta concepción poética, Novo podría dar siempre nuevas bellezas a la lírica hispanoamericana, pero le atrae demasiado la moda literaria y así en Elegía, poema inédito agregado a estas selecciones, se siente el aleteo del surrealismo. Aquí habla de sus manos "como un reptil que entrega su veneno", de su mirada en "donde brilla una ternura que se congela frente a las estatuas desnudas", de su cuerpo "como traje envejecido", de hombres que van ascendiendo y "brotan otras manos de sus manos para torcer el rumbo de los vientos o para tiernamente enlazarse".

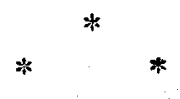

Xavier Villaurrutia, el poeta más joven del grupo "Contemporáneos" y uno de los artistas mejor dotados de México, publica su Nostalgia de la muerte. (I) Dentro de cierta marmórea frialdad, es esta poesía un dechado de aristocracia literaria. Villarrutia, siempre romántico, busca la novedad sólo en la expresión, pues su serie de nocturnos nos ofrece temas de aceptada frecuencia. Una pálida sonrisa de muerte juguetea en los labios del poeta:

Si mi muerte particular estuviera esperando una fecha, un instante que sólo ella conoce para decirme: "Aquí estoy".

En Nocturna rosa se afina su lirismo en sencillez y maestría técnica, en un juego de deliciosos contrastes:

Es la rosa encarnada de la boca, la rosa que habla despierta, como si estuviera dormida.

Es la rosa entreabierta de la que mana sombra, la rosa entraña que se pliega y expande

(I).-Xavier Villarrutia, Nostalgia de la muerte, Sur, Buenos Aires, $1938,76 \mathrm{p}$. 
evocada, invocada, abocada, es la rosa labial,

la rosa herida.

Nocturno mar es un poema lleno de personales sugerencias:

Nada, nada podrá ser más amargo

que el mar que llevo dentro, solo y ciego,

el mar antiguo Edipo que me recorre a tientas

desde todos los siglos...

En Décima muerte, para mí su mejor poema, llega a esa perfección a la vez ingenua y complicada de los poetas espanoles de fines del siglo XV. Nos parece ver y oír aquella maravilla de "ven muerte tan escondida", cuando leemos estrofas como ésta :

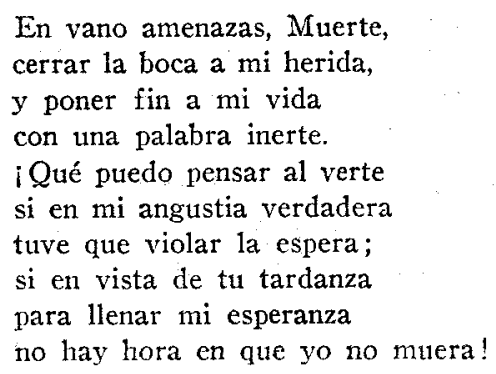

Nostalgia de la muerie encierra en el breve espacio de sus setenta y seis páginas belleza nueva y pura, de poeta rejuvcnecido, destructor del lugar común y de la metáfora gastada. Villaurrutia entra de lleno en la poesía de la lengua castellana, singularizado, consciente de su posición, definido, tanto en sus aciertos como en sus caprichos. En la poesía moderna de México, Villaurrutia pone una nota de clasicismo joven. En ella tiene ya prestigio de maestro.

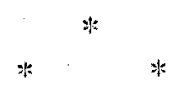

Así como Picasso escribe sus Poemas objetos, Elías Nan- 
dino se da el capricho de titular su libro, Poemas árboles, (r) demostrando así que está atento al movimiento de las nuevas categorías poéticas. En los sucesivos libros de Nandino se nota un progreso constante en la fórmula estética y en la arquitectura del verso. El deseo de decir bien y exactamente las cosas actúa en él como una obsesión. No satisface aún su anhelo de expresión, la definitiva forma "como si el agua anhelara sit forma precisa, como si la luz quisiera mirarse a sí misma, o como si todo el aire buscara su sitio". Romántico de temperamento, Nandino busca más allá de las formas físicas, ¡oh, eterna actitud metafísica de todo alto poeta! la solución del apetecido desear nunca logrado:

Me llamas por mi nombre y no te entiendo, yo te beso en la boca y no te siento...

versos en que se siente debajo de todo intento novedoso el ansia nunca satisfecha de la poesía de Enrique González Martínez.

El mar le atrae con esa fuerza y ese prestigio de las cosas desconocidas y lejanas. Sería interesante estudiar la influencia del mar en estos poetas del interior que nunca han visto el líquido elemento. Ese mar
que jugando como niño
repite su carrera eternamente, y con piernas de onda llega y toca
el espejo arenoso de la playa, y con rosas de espuma se devuelve a llamar otros niños a que salgan.

Atormenta a Nandino un macabro afán de visiones de ultratumba. En su inquietante Poema del miedo hay una pavorosa desolación, poema casi, trasmitida al poeta de la muda tragedia de las cosas:

Tengo miedo al semblante del espejo porque sabe que yo me estoy quemando

(1).-Elías Nandino, Poemas árboles, Ediciones "Norte", México, 1938, $64 \mathrm{p}$. 


\begin{abstract}
que ne hiere con ojos del cinismo, mientras él ya no siente mis incendios, porque goza tragedias que no sufre y otoña mi color con mis historias.
\end{abstract}

$\mathrm{Y}$ en Suicidio lento, un movimiento lento, un lento movimiento monótono, de muerte, de larga muerte, va desarrollando la angustia del poeta a través de imágenes indispensables, retorcidas, negras:

Suicidio entrelazado con mis días, más vivo cuanto más el goce apura, -exhausto, sudoroso, miel de angustia-pero siempre en acecho de mi cuerpo $y$ el color de mi sangre, como pulpo de fiebre que quisiera perderme en la succión de sus demonios.

Usa Nandino en su poesía imágenes nuevas, frías, grises, como vidrios rotos, como roces de navajas en acero. Inútil buscar en este poeta la sonrisa o la luz. Sombra y tedio le envuelven y en ellos flota, deshecho, como hombre mecánico, como hombre dentro de hombre.

Salvador Novo representa la ironía en la poesía de su patria; Xavier Villaurrutia, la más fina vibración estética del momento; Octavio Paz, el gesto heroico de la lucha social; Elías Nandino, la angustia, el miedo de las vísceras, en cavidades rojas, profundas, como largos túneles de sombra o corredores de hospital. 
